\title{
1. INTRODUCTION AND EXPLANATORY NOTES
}

\author{
The Shipboard Scientific Party ${ }^{1}$
}

Site 398 was drilled during Leg 47B of the Deep Sea Drilling Project $20 \mathrm{~km}$ south of Vigo Seamount (Figure 1) which is on the southern end of the Galicia Banks on the western Iberian continental margin. A total of 1740 meters of sediment was penetrated with excellent core recovery in water depth of 3900 meters. The sequence penetrated ranged in age from Hauterivian to Recent. A complete description of the objectives and results of the drilling is reported in the Site Report, wherein information on biostratigraphic zonations and absolute age scales used throughout this volume are included. Sigal (this volume) has developed a Cretaceous foraminiferal biostratigraphy for Site 398 which is shown here in Figure 2 and described elsewhere in the volume (Sigal, this volume).

Physical properties measurement methods (Mountain), the design and operation of the in-situ pore-water samples (Barnes), and explanatory notes are included herein.

\section{EXPLANATORY NOTES}

\section{Responsibilities for Authorship}

The Site Report in this volume presents the basic shipboard data and discussion of the general results of drilling during Leg 47B. The authorship of the site chapter is collectively that of the shipboard scientists with ultimate responsibility lying with the co-chief scientists, W.B.F. Ryan and J.-C. Sibuet. Compilation and checking was by Michael Arthur with the help of the editors, Fred Laughter and Evelyn Fagerberg. The order and authorship of each section of the Site Report are shown below:

Site Summary Data

Background and Objectives (Ryan and Sibuet)

\footnotetext{
'William B.F. Ryan (Co-Chief Scientist), Lamont-Doherty Geological Observatory, Palisades, New York; Jean-Claude Sibuet (CoChief Scientist), CNEXO, Brest, France; Michael A. Arthur, Princeton University, Princeton, New Jersey (present address: Scripps Institution of Oceanography, La Jolla, California); Boris G. Lopatin, Research Institute of the Geology of the Arctic, Leningrad, USSR; David G. Moore, Scripps Institution of Oceanography, La Jolla, California; Andres Maldonado, Instituto "Jaime Almera," Barcelona, Spain; Jean-Pierre Rehault, Université de Paris VI, Villefranches-sur-Mer, France; Silvia Iaccarino, University of Parma, Parma, Italy; Jacques Sigal, Institut Français du Pétrole, RueilMalmaison, France; Gerald E. Morgan, University of Leeds, Leeds, United Kingdom; Gretchen Blechschmidt, University of Washington, Seattle, Washington; Carol A. Williams, Lamont-Doherty Geological Observatory, Palisades, New York; David Johnson, Exxon Production Research Company, Houston, Texas; Ross O. Barnes, Walla Walla College, Anacortes, Washington; and Daniel Habib, Queens College of the City University of New York, Flushing, New York.
}

\author{
Operations (Ryan) \\ Lithology (Arthur with de Graciansky, Maldanado, \\ Mountain, Rehault, and Lopatin; Summary chart \\ compiled by Arthur) \\ Geochemistry (Arthur) \\ Physical Properties (Williams and Mountain) \\ Biostratigraphy: \\ Nannofossils (Blechschmidt) \\ Planktonic foraminifers (Iaccarino and Sigal) \\ Benthic foraminifers (Sigal) \\ Palynology (Habib) \\ Paleomagnetism (Morgan) \\ Correlation of Seismic Reflection Profiles With \\ Drilling Results (Sibuet and Williams) \\ Downhole Temperature Measurements (Ryan) \\ Summary and Conclusions (Sibuet)
}

\section{Survey and Drilling Data}

\section{Surveys}

The presite survey data, kindly supplied to the Leg 47 scientific staff by the various organizations and institutions active in the area and on which the site selection was based, is acknowledged in the site chapter.

A shipboard precision echo-sounder, together with seismic profiling equipment, was used to determine specific site locations. These data are discussed in the sections dealing with site approach. En route between sites, continuous observations were made of depth, magnetic field intensity, and sub-bottom structure. Underway depths were recorded on a Gifft precision graphic recorder (PGR). The depths were read on the basis of an assumed 800 fathoms/s sounding velocity. The sea depth (in m) was corrected (1) according to the tables of Matthews (1939) and (2) for the depth of the hull transducer, 6 meters below sea level. In addition, any depths referred to the drilling platform have been calculated under the assumption that this level is 10 meters above the water line.

The seismic profiling system aboard Glomar Challenger consisted of two Bolt airguns, a Scripps-designed hydrophone array, Bolt amplifiers, two bandpass filters, and two EDO recorders, usually recording at two different filter settings.

\section{Drilling Characteristics}

The taking of cores in a particular hole may be continuous, but more often is interspersed by drilled, but uncored, intervals of variable length (spot coring).

Due to circulation of water down the hole, drill cuttings are flushed out of the hole onto the sea bed (an “open system") and cannot be examined. 


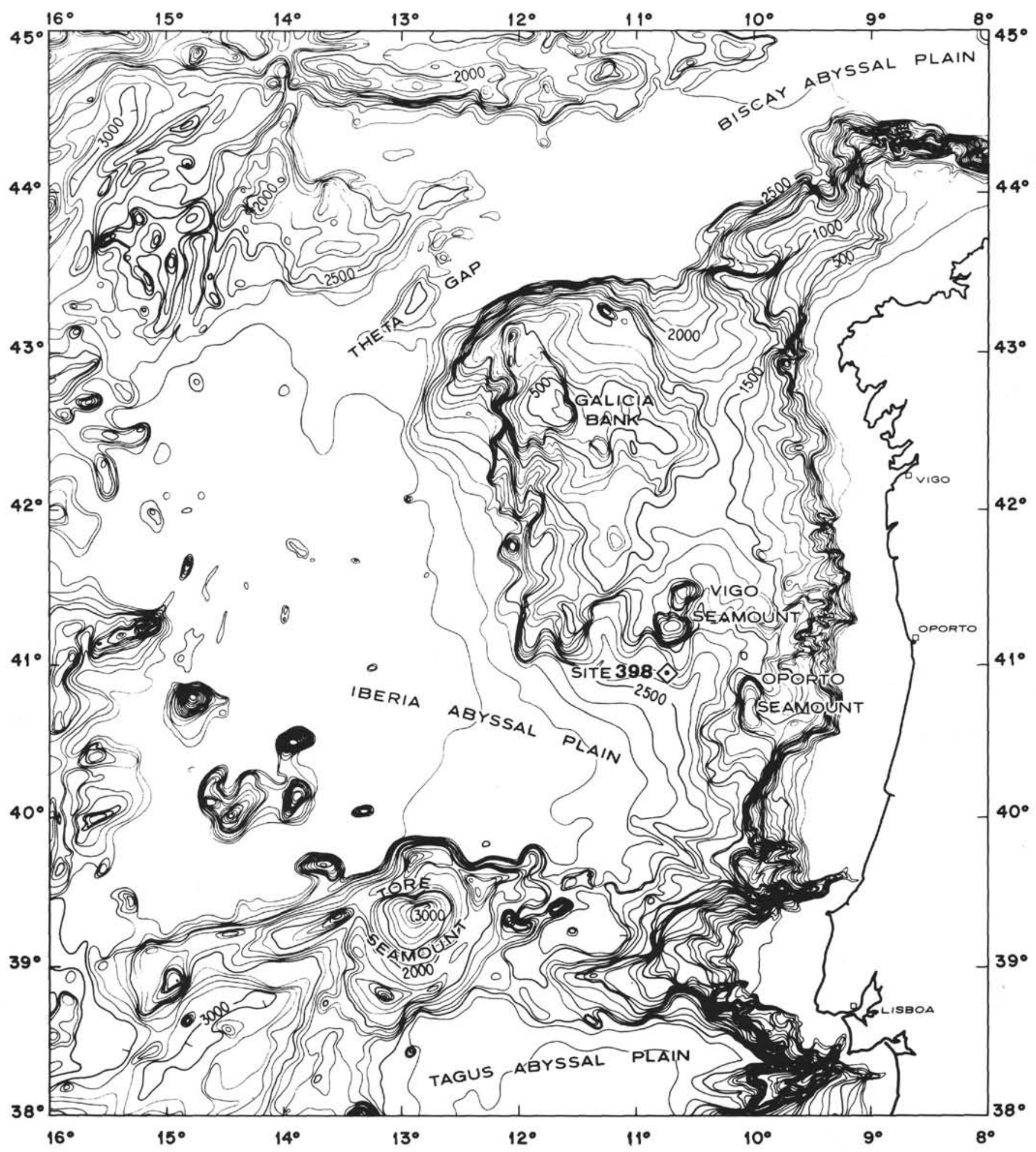

Figure 1. Site 398 location map.

The only information available about sedimentary material between cores, other than from seismic data, is from an examination of the behavior of the drill string as observed on the drill platform. The harder the layer being drilled, the slower and more difficult it is to penetrate. The most prominent of such layers are known as "drill breaks." There are, however, a number of other factors which determine the rate of penetration, so it is not possible to relate this directly to the hardness of the layers. The following parameters are recorded on the drilling recorder, and all influence the rate of penetration.

1) Weight on the bit. This can vary in three steps from zero, when the bit is suspended above the bottom 


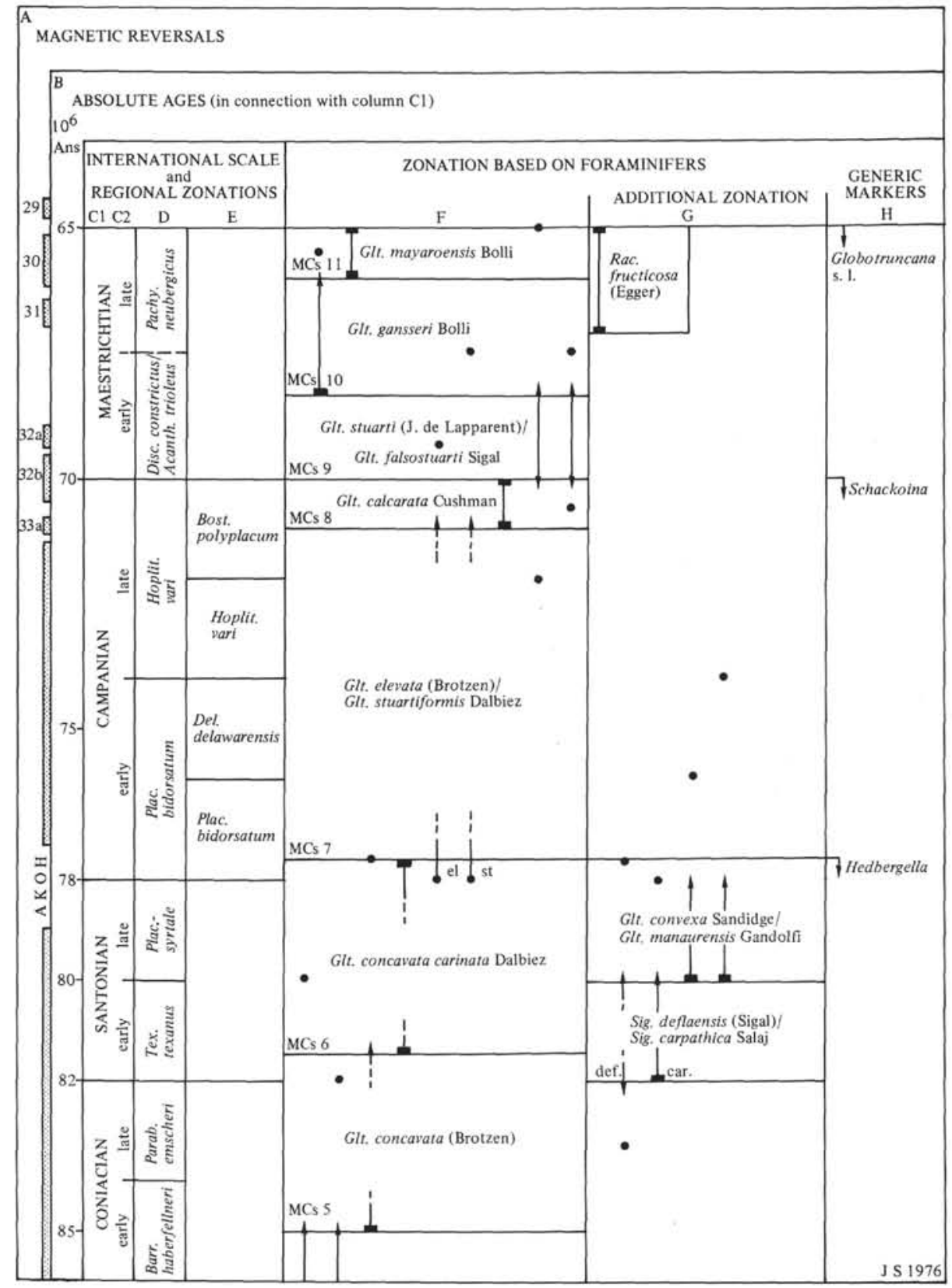

Figure 2. Tentative zonation for the Cretaceous in the Mediterranean areas based on planktonic foraminifers, (Sigal, this volume).

of the hole to 40,000 pounds when two of the three bumper subs are collapsed and the whole bottom assembly bears on the bit. The aim of the driller is, by reference to the weight indicator, to maintain constant bit weight by lowering the drill string when necessary. However, this is extremely difficult to do in conditions of swell, when the heave of the drill platform may exceed the available extension ( $6 \mathrm{ft}$ ) of the bumper subs.

2) Revolutions per minute. The revolutions per minute (rpm) are related to the torque applied to the top of the drill string, and a direct analysis of the two should give the resistance to drilling. However, the rpm record is not detailed enough to do this. Nevertheless, visual observations of the rate of drill string rotation are useful in assessing bit behavior. In particular, it can be seen that when the drill bit becomes jammed in very resistant rock, rotation stops, the bit becomes free and the drill string untwists.

\section{Drilling Disturbance}

Most cores, when split and examined aboard Glomar Challenger, show signs of having been disturbed to a greater or lesser extent by the drilling process. Such signs are the concave downward appearance of many originally horizontal bedding planes, the haphazard mixing of lumps of sediment having differing lithologies, and the near fluid state of some sediments. 


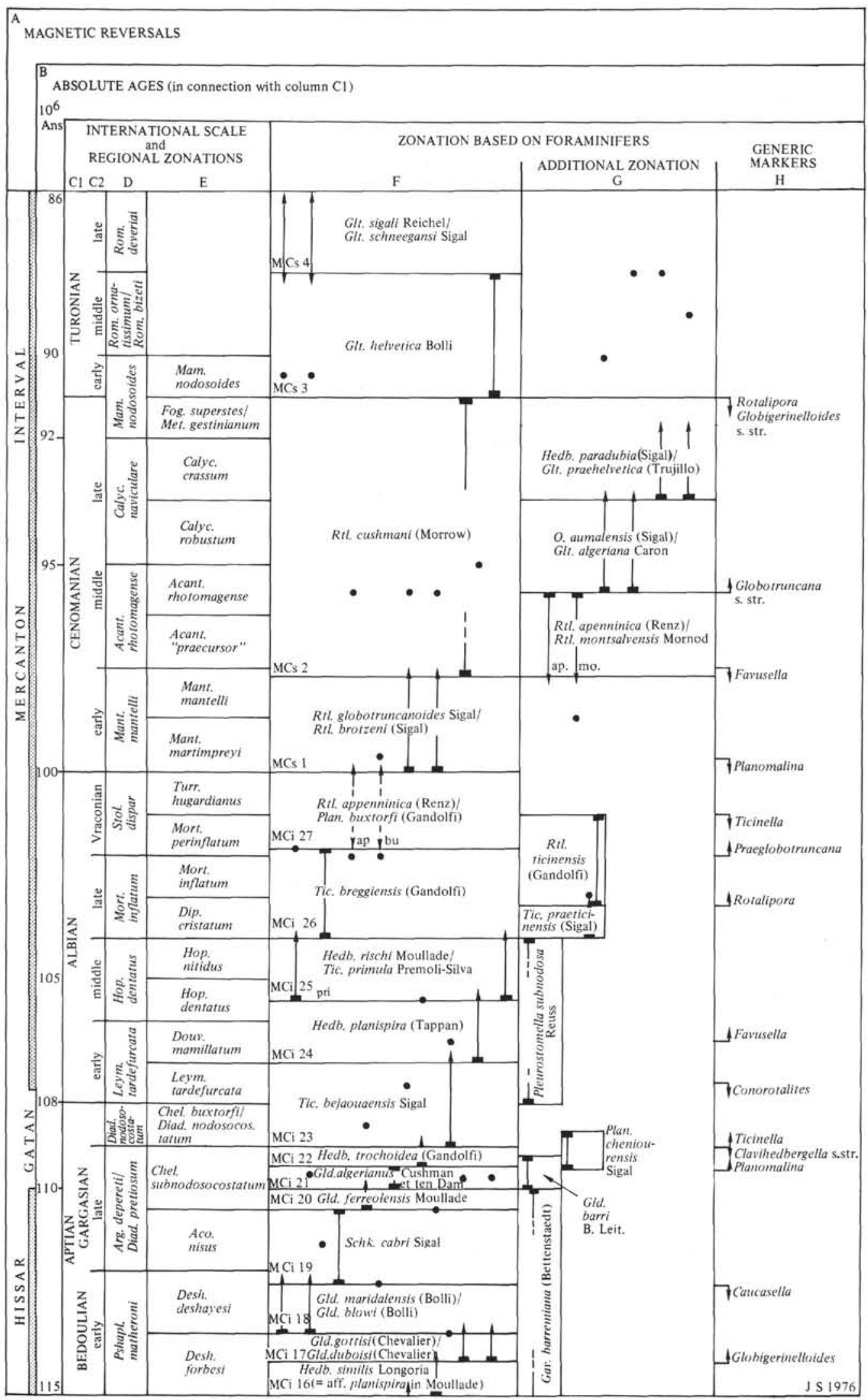

Figure 2. (Continued). 


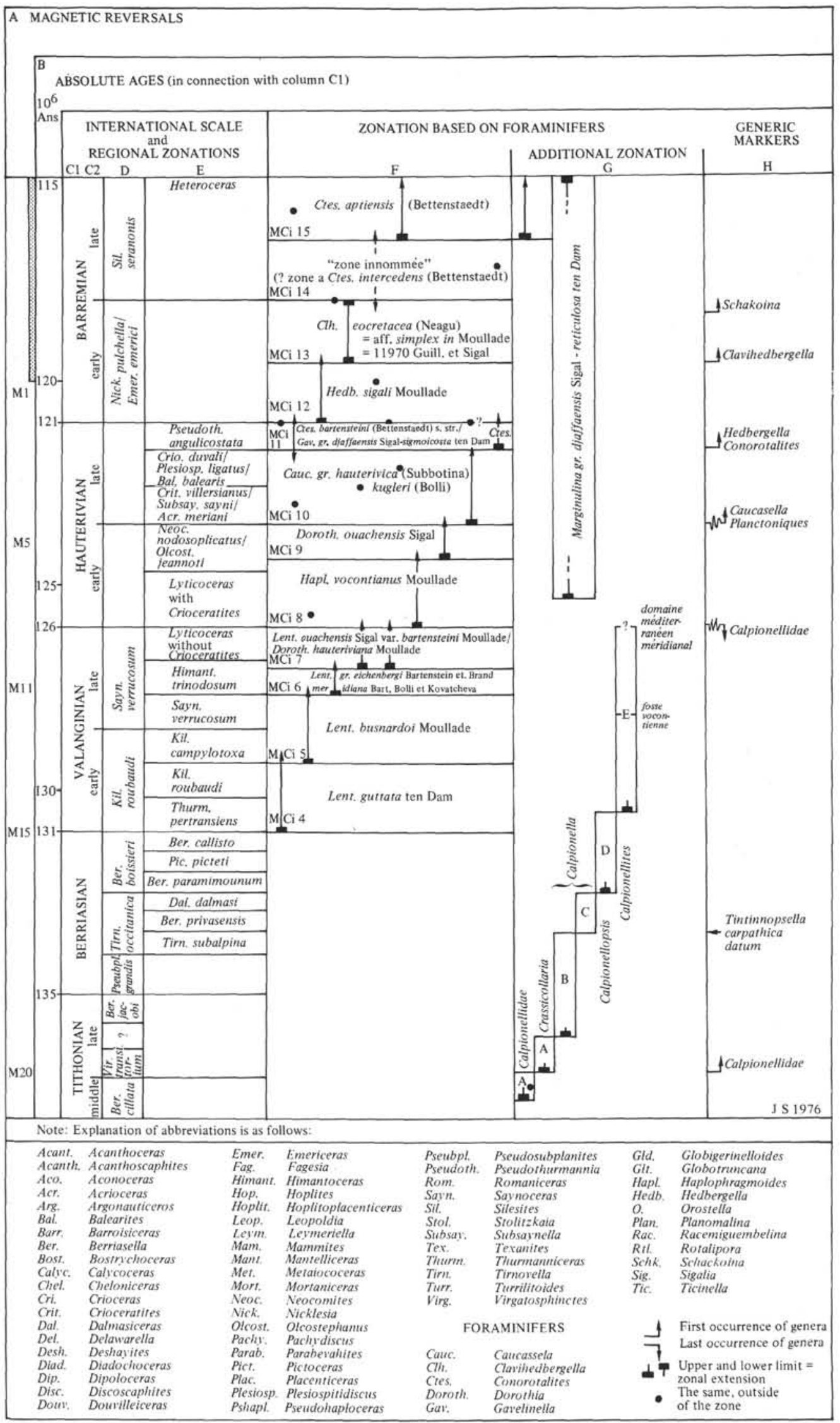

Figure 2. (Continued). 
Coring disturbance is particularly noticeable in the upper 100 meters or so of soft, unlithified sediments. At the other extreme, well-consolidated sedimentary and igneous rocks can also be reduced to rubble by the coring process. Variations in lithology are not the only factors determining the amount of coring disturbance. Differences in the type of drilling bit used and drilling techniques employed are also important. Clearly too, some sediment disturbance, and even some fracturing displayed by the cores, may be original predrilling features.

\section{Shipboard Scientific Procedures}

\section{Numbering of Sites, Holes, Cores, Samples}

Drill site numbers run consecutively from the first site drilled by Glomar Challenger in 1968, thus each site number is unique. A site refers to the hole, or holes, drilled while using one acoustic positioning beacon. Several holes may be drilled at a single locality by pulling the drill string above the sea floor ("mud line") and offsetting the ship some distance (usually $100 \mathrm{~m}$ or more) from the previous hole. This sometimes becomes necessary where there is insufficient soft sediment at the first location to "spud in" or bury the bottom-hole assembly (BHA).

The first (or only) hole drilled at a site takes the site number. Additional holes at the same site are further distinguished by a letter suffix. The first hole has only the site number; the second has the site number with suffix " $A$ "; the third has the site number with suffix "B"; and so forth. For example, four holes had been drilled at Site 398, therefore they should be referenced as Site 398 (first hole), Hole 398A (second hole), Hole 398B (third hole), etc. It is important for sampling purposes to distinguish the holes drilled at a site, since recovered sediments or rocks usually do not come from equivalent positions in the stratigraphic column at different holes.

Cores are numbered sequentially from the top down. In the ideal case, they consist of 9 meters of sediment or rock in a $6.6-\mathrm{cm}$-diameter plastic liner. In addition, a short sample is obtained from the core catcher (a multifingered device at the bottom of the core barrel which prevents cored materials from sliding out during corebarrel recovery). This usually amounts to about $20 \mathrm{~cm}$ of sediment and is stored separately. This sample, from each core, represents the lowest stratum recovered in the particular cored interval. The core-catcher sample is designated by CC (e.g., 398B-6, CC, is the core-catcher sample of the sixth core taken in the second hole drilled at Hole 398B).

The cored interval is the interval in meters below the sea floor measured from the point at which coring for a particular core was started to the point at which it was terminated. This interval is generally 9.5 meters (nominal length of a core barrel) but may be shorter if conditions dictate. Cores and cored intervals need not be contiguous. In soft sediment, the drill string can be "washed ahead" without recovering core by applying sufficiently high pump pressure to wash sediment out of the way of the bit. In a similar manner, a center bit, which fills the opening in the bit face, can replace the core barrel if drilling ahead without coring is necessary.

When a core is brought aboard Glomar Challenger, it is labeled and the plastic liner and core cut into 1.5-meter sections. A full, 9-meter core would thus consist of six sections, numbered from the top down, 1 to 6 . (The discrepancy between the 9-meter core and 9.5-meter core interval is discussed below.) Generally, somewhat less than 9 meters is recovered. In this case, the sections are still numbered starting with one at the top, but the number of sections is the number of 1.5-meter intervals needed to accommodate the length of core recovered; this is illustrated in Figure 3.

Thus, as shown, recovery of 3.6 meters of sediment would result in a core with three sections, with a void of 0.9 meter at the top of the first section. By convention, and for convenience in routine data handling at the Deep Sea Drilling Project, if a core contains a length of material less than the length of the cored interval, the sections that recovered material are placed in the top of the cored interval, with the top of Section 1 (not always the top of the sediment) located at the top of the cored interval. This is shown in Figure 4 for the core in the above example.

It was noted above that a discrepancy exists between the usual core interval of 9.5 meters and the 9-meter length of core recovered. The core liners used are actually 9.28 meters in length, and the core catcher accounts for another 0.2 meter. In cases where the core liner is recovered full to the top, the core is still cut into 1.5-meter sections, measured from the top.

Samples taken from core sections are designated by the interval in centimeters from the top of the core section from which the sample was extracted; the sample size, in $\mathrm{cc}\left(\mathrm{cm}^{3}\right)$, is also given. Thus, a full sample designation would consist of the following information:

Leg (Optional)

Site

(Hole, if other than first hole)

Core Number

Section Number

Interval in centimeters from top of section

Sample 398B-1-2, $122-124 \mathrm{~cm}\left(10-\mathrm{cm}^{3}\right)$ designates a $10-\mathrm{cm}^{3}$ sample taken from Section 2 of Core 1 from the second hole drilled at Site 398. The depth below the sea floor for this sample would then be the depth to the top of the cored interval plus 3 meters for Sections 1 and 2, plus $122 \mathrm{~cm}$ (depth below the top of Section 3). (Note, however, that subsequent sample requests should refer to a specific interval within a core section [in $\mathrm{cm}]$ rather than level $[\mathrm{m}]$ below sea floor.)

\section{Handling of Cores}

The first analysis of the material recovered by an individual core is the core catcher. Rapid paleontological and lithological analysis of this material from the base of the cored interval is carried out to make decisions as to whether to drill ahead or to take another core. 


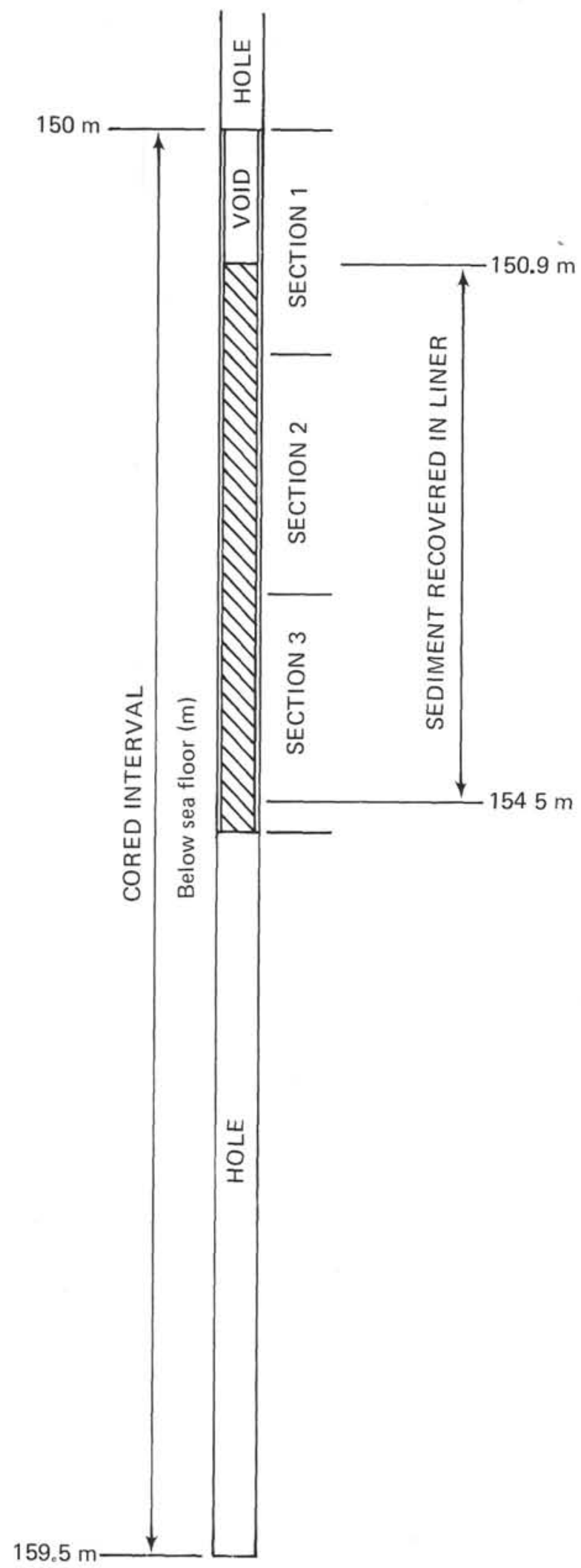

Figure 3. Position of incomplete sediment recovery within the cored interval.
After a core is brought up to the drill platform, it is cut, sealed, and labeled before beginning its routine progress through the shipboard analytical procedure. Often samples for organic geochemistry are taken at this stage.

In the core laboratory on Glomar Challenger, after physical property measurements requiring unsplit cores are made (such as thermal conductivity and densityporosity measurements using gamma ray attenuation techniques), the 1.5-meter sections of sediment core and liner are split lengthwise. One-half is designated the "archive" half, which is described by the shipboard sedimentologists and photographed; and the other is the "working" half, which is sampled by both the shipboard sedimentologists and paleontologists for further shipboard and shore-based analysis.

\section{Sampling}

In the core laboratory samples for routine shorebased analysis such as grain size, X-ray mineralogy and total carbonate content were taken from the working half, labeled, and sealed. Because of the high level of precruise interest in Leg 47B, samples were taken at this stage for numerous shore-based workers, whose contributions can be read in this volume. In addition, samples were regularly taken for immediate shipboard analysis, such as total carbonate by the "carbonate bomb" method. Routine samples were taken for smear slide, carbonate and grain-size analysis. The location of these samples is shown on the core forms in a column using appropriate symbols (see Sample Core Form, Figure 4). The working half was then sent to the paleontology laboratory, where samples for both shipboard and shore-based studies of nannofossils, foraminifers, radiolarians, diatoms, silicoflagellates, and other fossil groups were taken.

Material obtained from core catchers, and not used up in the initial examination, was retained (in freezer boxes) for subsequent work. Sometimes pebbles particularly important to the interpretation of the site were extracted from the core and stored separately in labeled containers as a measure against loss. On occasions where the liners contained only sediment-laden water, the water was usually collected in a bucket, allowed to settle, and the residue was stored in freezer boxes. All samples are deposited in cold storage at the DSDP East Coast Repository at Lamont-Doherty Geological Observatory and are available to investigators.

\section{Lithologic Studies}

The archive half of the split section is used only for descriptive purposes. The cut surface of each is scraped to emphasize the sedimentary features and the color, texture, structure, and composition of the varying lithologies. Each section is described individually on a Visual Description Form. Smear slides are made and are examined using the shipboard petrographic microscopes. These, in conjunction with the "carbonate bomb" results, provide the basic shipboard information on lithology. The archive half is then photographed. 


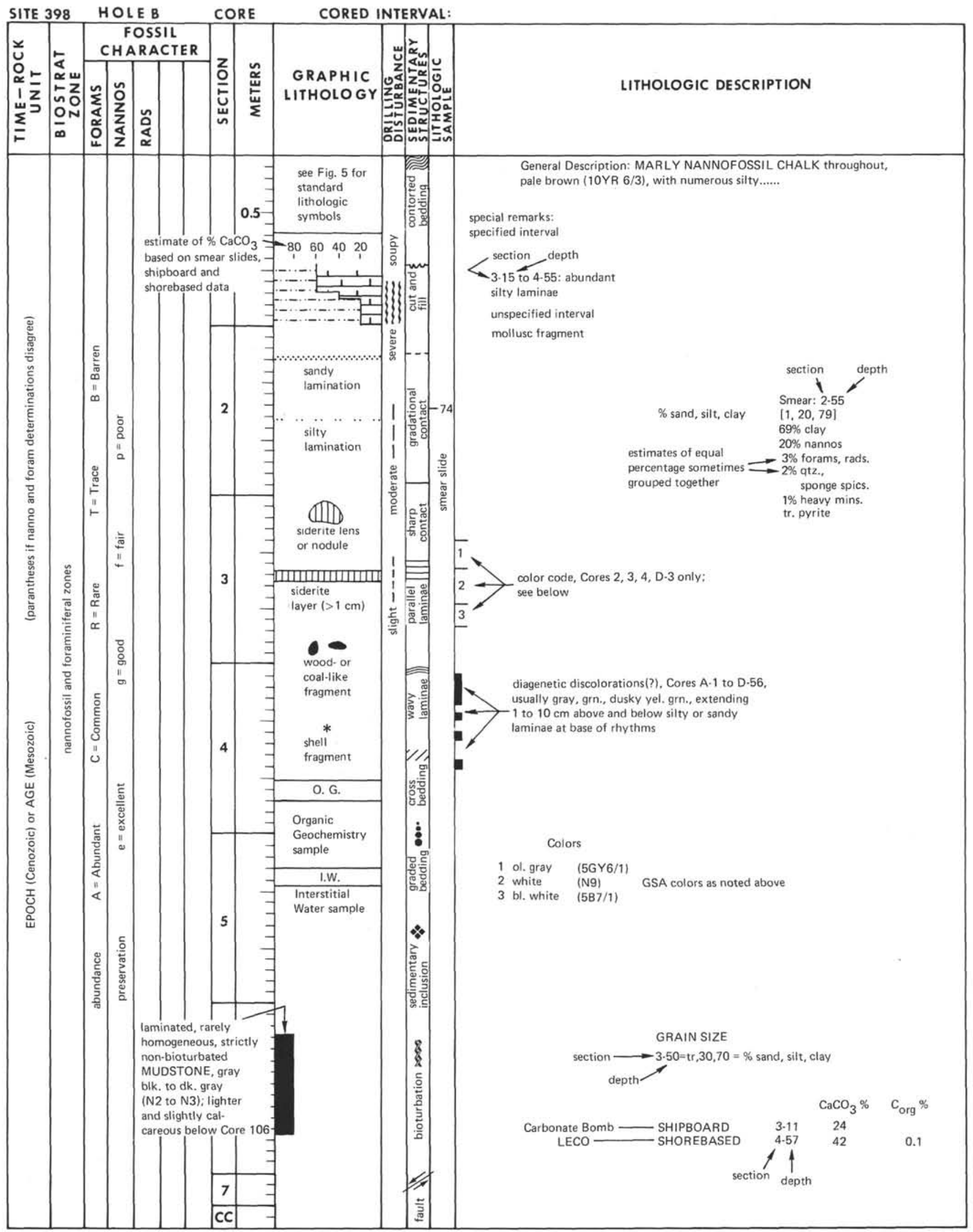

Figure 4. Sample core form. 


\section{Core Forms}

The basic descriptive data, both lithologic and biostratigraphic, for each section of a particular core are combined to produce the Core Summary Forms, which accompany each site chapter. These are first compiled aboard ship, but are upgraded later using postcruise shore-based data. A sample core form is illustrated in Figure 4. Most data are symbolized, but a short description is provided giving the essential lithologic information in the following order: Sediment or rock name, Sediment disturbance, Color name and Munsell or GSA number, Sedimentary structures and other special features, Composition from smear slides and bulk X-ray analysis, Grain-size and carbonate data. Many cores contain important minor lithologies as well as a basic lithology. The description of the major lithology is so indicated in most cases; however, descriptive information for minor lithologies is included wherever possible.

As noted previously, the rotary drill-coring technique quite often results in disturbance of the cored sediments. This is especially true of the softer unconsolidated sediments. A qualitative estimate of the degree of deformation is given as a symbol on the core logs.

Color names and numbers are derived by reference to the GSA Rock Color Chart (Goddard et al., 1963). The reader is advised that colors recorded in core barrel summaries were determined during shipboard examination immediately after splitting core sections. Experience with carbonate sediments shows that many of the colors will fade or disappear with time, after opening and storage. Colors particularly susceptible to rapid fading are purple, light and medium tints of blue, light bluish gray, dark greenish black, light tints of green, and pale tints of orange. These colors change to white or yellowish white or pale tan.

\section{Smear-Slide Analysis}

Smear slides are prepared from minute amounts (1 or $2 \mathrm{~mm}^{3}$ ) of sediment taken with a spatula, puddled and smeared with distilled water on a glass slide, dried, and set under a cover-slip with Caedex. Their examination by petrographic microscope provides a rapid means of mineral identification. They are the basic source of lithologic information used onboard ship, although thin sections are used in studies of basalts and other hard rocks.

Smear-slide estimates of mineral abundances are based on the percentage of the area of the smear slide covered by each component. Past experience has shown that accuracy may approach a per cent or so for very distinctive minor constituents, but that for major constituents, accuracy of \pm 10 per cent is considered very good. The accuracy of this technique aboard ship is much enhanced when employed, as on Leg 47B, in conjunction with numerous carbonate bomb measurements (see below).

\section{“Carbonate Bomb" Data}

During Leg 47B, extensive use was made of the "carbonate bomb" device (Müller and Gastner, 1971) as an aid in sediment classification. All total carbonate percentages measured by this method are recorded on the core summary forms, as are levels of sampling (B). Accuracy to within \pm 5 per cent total carbonate has been quoted for the device. However, postcruise shorebased studies suggest that it may be somewhat less accurate than this, particularly for high carbonate sediments or for complex mixtures of sedimentary components where carbonate is low (see below). Also the "bomb" device is probably considerably less accurate where dolomitic sediments are encountered.

When $\mathrm{CO}_{2}$ pressure readings on the carbonate bomb are in the range 0.40 to 0.65 , both methods (LECO and bomb) did give comparable values with a maximum difference of \pm 5 per cent $\mathrm{CaCO}_{3}$ (weight). With $\mathrm{CO}_{2}$ pressure readings on the "bomb" in the range 0 to 0.40 , the LECO values were higher by 7 to 12 per cent $\mathrm{CaCO}_{3}$ (weight) in the lower half of the range and by 1 to 7 per cent (weight) in the upper part. With $\mathrm{CO}_{2}$ pressure readings on the "bomb" above 0.65 the LECO values are lower, by 1 to 13 per cent $\mathrm{CaCO}_{3}$ (weight).

The LECO method (combustion by inductive heating in an $\mathrm{O}_{2}$ atmosphere) is considered more reliable than the "carbonate bomb" method.

A scan of the $\mathrm{CaCO}_{3}$ values recorded on the core summary forms for both shipboard "carbonate bomb" and DSDP shore-based LECO measurements reflects the conclusions arrived at above. However, it is important to note that the "carbonate bomb" device is employed aboard Glomar Challenger primarily as an aid in the accurate naming of sediments in conjunction with the smear slide observations and that within the bounds of the JOIDES sediment classification, the discrepancies noted would not change the names given to sediments onboard ship.

\section{Sediment Classification}

The sediment classification used on Leg 47B was devised by the JOIDES Panel on Sedimentary Petrology and Physical Properties, and adopted for use by the JOIDES Planning Committee in March 1974. It is reproduced in part below.

The only modification found necessary to the JOIDES classification itself was to the "Transitional Biogenic Calcareous Sediments" category; that is, the marls and marlstones $\left(>30\right.$ per cent $\mathrm{CaCO}_{3}$ and $>30$ per cent silt and clay). The existing single symbol/ category was split into five, taking into account dolomite content, and now includes: marls, marlstones, dolomitic marls, dolomitic marlstones, and dolomitic muds and mudstones.

\section{Lithologic Classification Scheme}

The following define compositional class boundaries and use of qualifiers in the lithologic classification scheme:

1) Compositional Class Boundaries

a) $\mathrm{CaCO}_{3}$ Content (determined by carbonate bomb): 30 and 60 per cent. With a 5 per cent precision and given the natural frequency distribution of $\mathrm{CaCO}_{3}$ contents in oceanic 
sediments, these boundaries can be reasonably ascertained.

b) Biogenic Opal Abundance (expressed as per cent siliceous skeletal remains in smear slides): 10,30 , and 50 per cent. Smear slide estimates of identifiable siliceous skeletal material generally imply a significantly higher total opal abundance. The boundaries have been set to take this into account.

c) Abundance of Authigenic Components (zeolites, $\mathrm{Fe}$, and $\mathrm{Mn}$ micronodules, etc.), fish bones, and other indicators of very slow sedimentation (estimated in smear slides); semiquantitative boundary: common 10 per cent. These components are quite conspicuous and a semiquantitative estimate is adequate. Even a minor influx of calcareous, siliceous, or terrigenous material will, because of the large difference in sedimentation rate, dilute them to insignificance.

d) Abundance of Terrigenous Detrital Material (estimated from smear slides): 30 per cent.

e) Qualifiers: Numerous qualifiers are suggested; the options should be used freely. However, components of less than 5 per cent (in smear slide) should not be used as a qualifier except in special cases. The most important components should be the last qualifier. No more than two qualifiers should be used.

\section{Description of Sediment Types}

1) Pelagic Clay-Principally authigenic pelagic deposits that accumulate at very slow rates. The class is often termed brown clay, or red clay, but since these terms are confusing, they are not recommended.

a) Boundary with Terrigenous Sediments: Where authigenic components (Fe/Mn micronodules, zeolites), fish debris, etc., become common in smear slides. NOTE: Because of large discrepancy in accumulation rates, transitional deposits may be exceptional.

b) Boundary with Siliceous Sediments: 30 per cent identifiable siliceous remains.

c) Boundary with Calcareous Biogenous Sediments: Generally the sequence is one passing from pelagic clay through siliceous ooze to calcareous ooze, with one important exception: at the base of many oceanic sections, black, brown or red clays occur directly on basalt, overlain by or grading up into calcareous sediments. Most of the basal clayey sediments are rich in iron, manganese and metallic trace elements. For proper identification they require more elaborate geochemical work than is available onboard. These sediments are placed in the "Special Rock" category, but care should be taken to distinguish them from ordinary pelagic clays.

2) Pelagic Siliceous Biogenic Sediments-These are distinguished from the previous category because they have more than 30 per cent identifiable siliceous microfossils. They are distinguished from the following category by a $\mathrm{CaCO}_{3}$ content of less than 30 per cent. There are two classes: Pelagic biogenic siliceous sediments (containing less than 30 per cent silt and clay); and transitional biogenic siliceous sediments (containing more than 30 per cent silt and clay and more than 10 per cent diatoms).

a) Pelagic biogenic siliceous sediments:

soft: Siliceous ooze (radiolarian ooze, diatomaceous ooze, depending on dominant component).

hard: radiolarite porcelanite diatomite chert

(i) Qualifiers:

Radiolarians dominant: radiolarian ooze or radiolarite.

Diatoms dominant: diatom ooze or diatomite.

Where uncertain: siliceous (biogenic) ooze, or chert.

(ii) Qualifiers-In this group numerous qualifiers are possible usually based on minor constituent, for example: glauconitic, pyritic, feldspathic.

In the sand and sandstone category, conventional divisions such as arkose, graywacke, etc., are, of course, acceptable, providing the scheme is properly identified. Clays, muds, silts, and sands containing 10 to 30 per cent $\mathrm{CaCO}_{3}$ shall be called calcareous.

b) Volcanogenic sediments: Pyroclastic rocks are described according to the textural and compositional scheme of Wentworth and Williams (1932). The textural groups are:

$\begin{array}{ll}\text { Volcanic breccia } & >32 \mathrm{~mm} \\ \text { Volcanic lapilli } & <32 \mathrm{~mm} \\ \text { Volcanic ash (tuff, if indurated) } & <4 \mathrm{~mm}\end{array}$ Compositionally, these pyroclastic rocks are described as vitric (glass), crystal or lithic.

c) Clastic sediments of volcanic provenance are described in same fashion as the terrigenous sediments, noting the dominant composition of the volcanic grains where possible.

5) Special rock types - The definition and nomenclature of sediment and rock types not included in the system described above are left to the discretion of shipboard scientists with the recommendation that they adhere as closely as practical to conventional terminology.

In this category fall such rocks as:

Intrusive and extrusive igneous rocks; Evaporites, halite, anhydrite, gypsum (as a rock), etc.;

Shallow water limestone (biostromal, biohermal, coquina, oolite, etc.);

Dolomite;

Gravels, conglomerates, breccias;

Metalliferous brown clays;

Concretions, barite, iron-manganese, phosphorite, pyrite, etc.; 
Coal, asphalt, etc.;

and many others.

The mandatory graphic lithology column should be completed by shipboard staff with appropriate symbols for intervals containing special rock types. It is imperative that symbols and rock nomenclature be properly defined and described by shipboard staff.

\section{Lithologic Symbols}

Figures 5 and 6 display the set of lithological and structure symbols pertinent to and employed during Leg 47B. These symbols are used on the Core Summary Forms. Figure 7 is the standard lithologic symbols that accompany the JOIDES sediment classification.

\section{Hole Summary Diagrams}

For each hole a summary diagram is drawn and accompanies each site chapter. This is primarily a compilation of the lithologic and biostratigraphic data displayed on the core forms. Again these are initially drawn aboard ship and are later modified to take account of shore-based data. Downhole plots of carbonate content and X-ray mineralogical data accompany each diagram.

\section{Lithostratigraphic Terminology}

Many different lithologies were encountered on Leg 47B. No formal rock stratigraphic units are employed in the site chapter. The sediments are informally divided into units and sub-units. For each site, these unit designations are outlined in a table in the lithology section and also in the appropriate hole summary diagram. Boundaries between specific units and sub-units in cored intervals were both sharp and gradational. If a boundary occurred between cores, it was placed in the middle of the drilled interval, unless biostratigraphic evidence deemed otherwise.

\section{Routine Shore-Based Analyses}

In a number of cases sediment names have been modified from those given aboard ship to take into account the shore-based data.

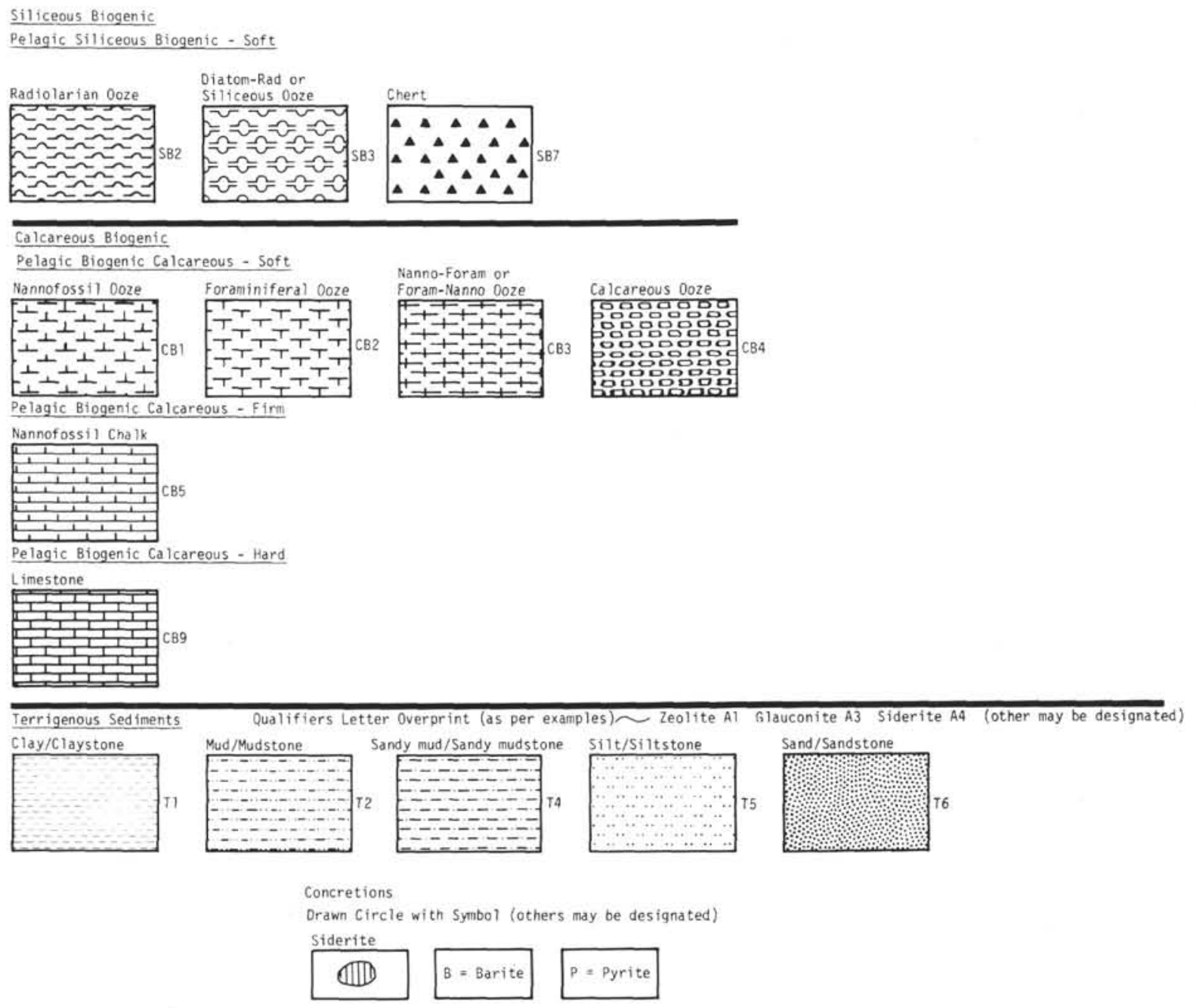

Figure 5. Graphic symbols to accompany the lithologic classification scheme used on Leg 47B. 
BIOTURBATION

BURROWS

GRADED BED

GRADATIONAL CONTACT

(hand drawn)

SHARP CONTACT

(hand drawn)

PARALLEL

LAMINATIONS

CROSS STRATIFICATION

MASSIVE OR HOMOGENEOUS

(no symbols necessary)

SEDIMENTARY CLASTS

SLUMP

Figure 6. Sedimentary structure symbols.

\section{Carbon-Carbonate Analyses}

Shore-based carbon-carbonate analysis was with a LECO acid-base semi-automatic carbon determinator. Step-by-step procedures used at the DSDP La Jolla Laboratory are reported in Bader et al. (1970), and a discussion of the method, its calibration, and its precision can be found in Boyce and Bode (1972).

Total carbon and organic carbon (carbon remaining after treatment with hydrochloric acid) are determined in terms of weight per cent, and the theoretical percentage of calcium carbonate is calculated from the following relationship:

\section{Per cent calcium carbonate $\left(\mathrm{CaCO}_{3}\right)=$ ( $\%$ total $\mathrm{C}-\% \mathrm{C}$ after acidification) $\times 8.33$}

However, carbonate sediments may also include magnesium, iron, or other carbonates; this may result in "calcium" carbonate values greater than the actual content of calcium carbonate. In DSDP determinations, all carbonate is assumed to be calcium carbonate.

Precision of the determination is as follows:

Total carbonate

(within 1.2 to $12 \%$ )

Total carbon (within 0 to $1.2 \%$ )

Organic carbon
Calcium carbonate

(within 10 to $100 \%$ )

(within 0 to $10 \%$ )

$$
\begin{aligned}
& = \pm 3 \% \\
& = \pm 1 \%
\end{aligned}
$$

absolute

absolute

Grain-Size Analyses

The DSDP shore-based grain-size analyses, presented on the Core Summary Forms were derived by standard sieve and pipette techniques, as described in detail in Bader et al. (1970), with modified settling times as in Boyce (1972).

\section{Geochemical Measurements}

Shipboard geochemical measurements were routinely made during Leg 47B. The standard DSDP procedures for interstitial water and allied studies were employed. These are adequately described in Waterman (1970) and in Whitmarsh, Weser, Ross, et al. (1974).

\section{Physical Properties}

Physical property measurements of bulk wet density, porosity, permeability, water content, compressional velocity, and shear strength were made during Leg 47B. The measurement techniques and sampling considerations have been carefully described by Boyce (1973) and will only be outlined briefly in the following discussion. Further discussions of the routine physical property measurements, centering principally on certain problems with the techniques and their effects on the quality of the data, can be found in a paper by Bennett and Keller (1973). Anyone intending to draw geologically relevant conclusions based on the physical property data presented in this volume is urged to read both papers. At drill sites where downhole temperature data were obtained, thermal conductivity measurements were made in order to permit calculation of the rate of heat flow through the sea floor. Methods of downhole temperature measurement are described in the Site Report (this volume).

\section{Sonic Velocity Data}

Measurements of compressional wave velocities in sediments were made using the Hamilton frame apparatus (see Mountain, this volume). All measurements were made at room temperature and pressure after the cores had reached thermal equilibrium with the laboratory, and soon after they were opened. Most of the data are obtained by measuring the length of time required for sound to traverse a path through the sediment and plastic core liner between a $400-\mathrm{kHz}$ acoustic transducer and receiver. This method assumes good acoustic contact between the liner and the sediment, a condition which may not be fulfilled if the sediment does not completely fill the core liner. Corrections must be made to account for the thickness of the liner and the length of time required for the sound to pass through the liner. The corrections routinely applied presuppose liners of constant sound velocity and thickness. The second parameter, thickness, is known to vary widely from shipment to shipment and even within a given section of liner. Thus measurements of sound velocity of material in a split liner are subject to errors not present when measurements are made directly on material consol- 
Pelagic

Non-biogenic

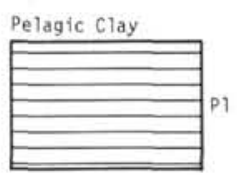

Silfceous Biogenic

Pelagic Siliceous Biogenic - Soft

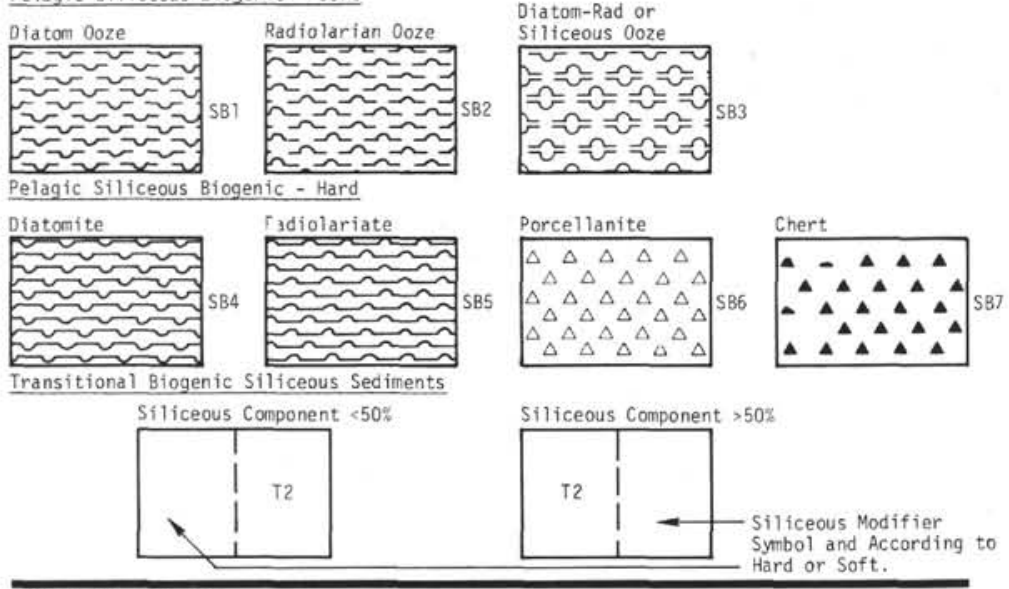

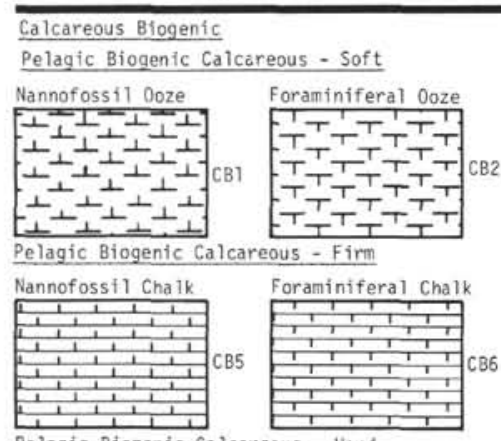

Pelagic Biogenic Calcareous - Hard

Limestone

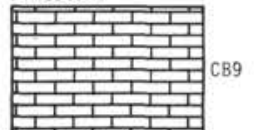

Nanno-Foram or

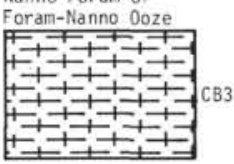

Nanno-Foram or

Calcareous cha $1 \mathrm{k}$

Calcareous Chalk
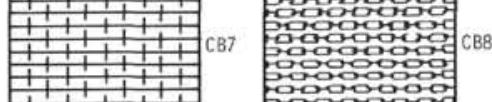

Transitional Biogenic Calcareous Sediment

Transitional Biogenic Calcareous Sediments
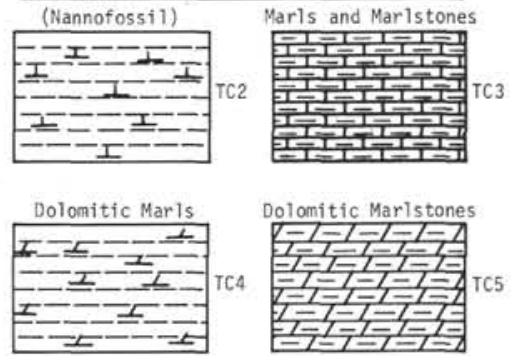

Dolomitic Muds and

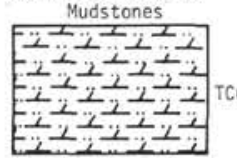

Special Rock Types

\section{Pyroclastic}
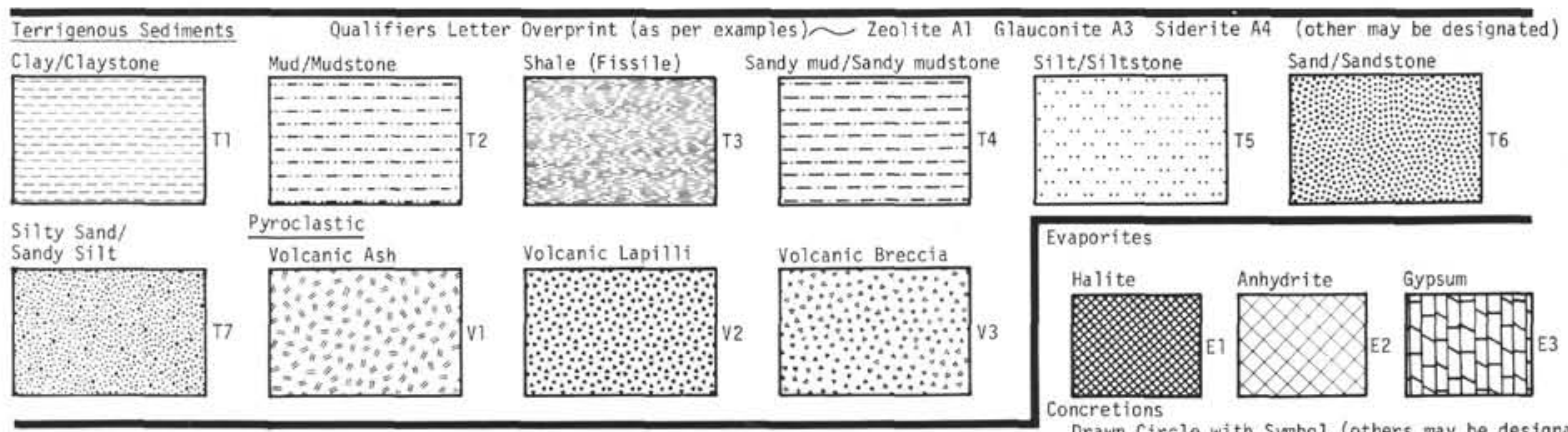

Drawn Circle with Symbol (others may be designated)

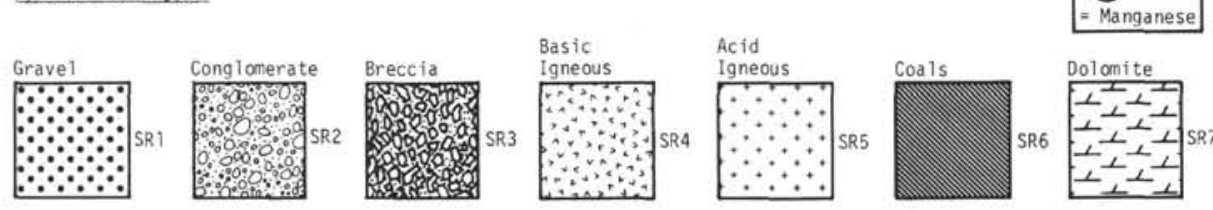

Figure 7. Graphic symbols to accompany the JOIDES lithologic classification scheme. 
idated enough to be shaped and put between the transducers.

Where consolidation was sufficient, the ends and sides of chunks of unsplit core were cut or shaped into flat, parallel faces with normals parallel and perpendicular to the long axis of the core, taking care to minimize disturbance to the sample. The velocity was determined directly on these chunks in both directions, and the horizontal and vertical velocities could then be compared in order to detect the presence of seismic anisotropy.

On Leg 47B, a substantial difference was found to exist between horizontal velocities (parallel to bedding) routinely measured through the liner in split cores, and the vertical velocities required to compute the thickness of sedimentary layers from travel time data. Thus it is clear that neglect of acoustic anisotropy can seriously affect realistic interpretation of seismic data from drilling results.

\section{Gravimetric Data}

Bulk property measurements were made on sediment samples obtained from the central, presumably undisturbed portion of the sediment cores using small $(<1$ $\left.\mathrm{cm}^{3}\right)$ syringe-type samplers and larger $\left(\cong 20 \mathrm{~cm}^{3}\right)$ stainless steel cylinders of known volume. The sediment samples were weighed wet and again after drying at $110^{\circ} \mathrm{C}$ for 24 hours and computations of bulk wet density, porosity, and water content were made.

The extremely small volume of the syringe sample can result in substantial errors in measuring both weight and volume differences, and the small diameter of the syringe makes representative sampling of coarse-grained, highly porous and/or well-compacted sediments almost impossible. Comparison of the wet bulk density data taken with the two techniques indicates that the variability of the syringe data is much higher than that of data obtained using the cylinder-sampling technique. Further comparison of the syringe data with densities measured using the larger volume cylinder samples, as well as with densities determined by gamma ray attenuation methods, suggests that the syringe density data may be systematically low. The standard deviation of the syringe data is approximately twice as large as the standard deviations of the density values obtained using the other two measurement methods. Thus bulk-properties determined using syringe sampling techniques cannot be used to define any other than the most dramatic changes in sediment physical properties.

The larger volume of the samples obtained using the stainless steel cylinders permits a significant reduction in the errors in the volume and weight measurements. The sampling procedure was to push the sharpened end of a thin-walled cylinder of known weight and volume into the sediment until its lower end made contact with the curved wall of the core liner and its upper end was slightly buried beneath the surface of the freshly split core. Pliers were then used to gently rock the cylinder back and forth in order to break suction between the bottom of the sediment sample and the inside of the core liner. The cylinder was withdrawn with the sediment protruding from both ends and the sediment was carefully shaved and cut back until it was flush with the end of the cylinder. This ensured that the volume of sediment was the same as the previously measured internal volume of the cylinder. The sediment-filled cylinder was then weighed and dried for at least $24 \mathrm{hr}$ at $110^{\circ} \mathrm{C}$, after which it was weighed again.

Representative sampling was difficult in coarsegrained sediments due to the tendency for the larger grains to dig into the surface of the sample as the ends were being smoothed. In poorly compacted, plastic sediments the friction of the sediment plug against the inside of the cylinder tended to compress the plug or prevent it from entering the cylinder smoothly, thus causing some mechanical disturbance. In more compact sediments the cylinder tended to fracture the sediment before it had become fully inserted, or to break the plug loose from the remaining sediment in such a way that the ends of the plug did not protrude from, or even reach, the ends of the cylinder. In these cases where the volume was not accurately known the sample was only used to determine water content.

In sediments which could be sampled effectively, plexiglass plates were fastened over the ends of the cylinder to prevent drying, and the attenuation of gamma rays through both the plexiglas and the sample was determined, thus permitting calculation of the wet bulk density, on the basis of gamma ray attenuation data. In this way the bulk-wet density values obtained using both gravimetric and gamma ray attenuation techniques could be compared and the gamma ray attenuation technique could be calibrated using the more direct gravimetric data.

\section{GRAPE Data}

Measurement of the attenuation of a pencil-sized beam of gamma rays passing through a known thickness of sediment (or rock) permits calculation of the bulk wet density and porosity of the material. The accuracy of the method as applied to sediment or rock is strongly dependent upon the homogeneity, consistency, and dimensional stability of the sediment as it passes through the gamma ray beam. Because of coring disturbance and the mechanical properties of the sediment, it is common for very soft or very hard sediment to only partially fill the core liner. Often a core of relatively undisturbed sediment or rock will have a variable and smaller diameter than the inner diameter of the core liner. The length of the gamma ray path through both the sediment and through the air, water, or slurry between the sediment core and the walls of the core liner must be known in order to compensate for the effects of the varying geometry. Furthermore, the wet bulk density of the surrounding slurry, if any, must be measured separately using gravimetric techniques in order to correct for the presence of material other than the undisturbed portion of the core itself. All of these variables 
are difficult to estimate accurately and are time consuming to measure. If neglected, they can produce both highly variable and anomalously low values of wet bulk density values and high values of porosity. The most representative wet bulk density values for a particular type of sediment are probably the maximum values recorded. However, it is worth noting that the expulsion of interstitial fluids because of compaction during coring can produce higher wet bulk density values than the actual in-situ density. Great care must be taken in drawing geological deductions from data obtained using the gamma ray attenuation technique.

\section{Shear Strength}

Measurements of the shear strength of sediment were made. The values were obtained by measuring the torque required to shear the sediment as it was applied to a four-bladed rectangular vane having known width and height. The method is capable of providing meaningful quantitative data for clayey sediments. However, when used for sediment types other than clays, the interpretation of the data becomes much more qualitative.

\section{OPERATION OF THE IPOD IN-SITU PORE WATER SAMPLE (Ross O. Barnes)}

\section{Introduction}

A new downhole instrument designed to filter and collect pore waters from sediments undisturbed by the drilling operation was tested for the first time on Leg 47B. The IPOD in-situ pore-water sampler will be used to collect geochemical information not obtainable by other means.

Pore fluid samples are routinely obtained on the D/V Glomar Challenger by pressure filtration of recovered core sections. Chemical speciation in the pore fluids can be altered during this procedure by a variety of mechanisms. Temperature and pressure changes during core recovery can alter ion-exchange equilibria between solid and liquid phases. Reduced sediments can be partially oxidized by exposure to oxygenated waters and the atmosphere. Disturbance of the sediment core by the drilling operation and the long residence time of the core in the drill pipe may lead to significant sea water contamination. Escape of $\mathrm{CO}_{2}$ from the core material can alter speciation in the carbonate system and lower the alkalinity of the recovered pore water. In-situ collected pore-water samples can reduce or eliminate these disturbances, thereby providing a valuable check on the accuracy of conventional pore-water chemical data.

For accurate dissolved gas concentration measurements, squeezed pore-water samples are not satisfactory because of gas loss and exchange during core recovery and processing (Barnes, 1973). Pore-water samples from Glomar Challenger drilling operations that are suitable for dissolved gas analysis would be valuable for several studies. (1) Inert gas concentration profiles are required for investigation of crustal degassing of helium (Barnes and Bieri, 1976); possible paleotemperature data deduced from inert gas ratio measurements (Mazor, 1972); and investigation of the cause of anomalous inert gas concentrations in sedimentary pore waters (Barnes, in preparation). (2) We wish to investigate the interrelationships of various reactions occurring during the biogeochemical cycling of carbon, nitrogen, and sulfur. $\mathrm{N}_{2}$ and $\mathrm{N}_{2} \mathrm{O}$ are produced during devitrification and low molecular weight hydrocarbons are produced during anoxic decomposition of organic matter. Does the sequence and relationship of the oxidation-reduction reactions in these systems vary with the rate of reaction? IPOD pore-water samples provide a time domain not accessible to surface coring techniques.

\section{Theory of Operation}

To accomplish the above objectives, pore water from sediment undisturbed by the drilling operation must be filtered from the solid-phase in situ and sealed against gas loss and atmospheric contamination until chemical or gas analysis is performed.

The IPOD in-situ sampler utilizes the in-situ hydrostatic pressure to force pore water through a fine stainless mesh filter into a $0.476 \mathrm{~cm}$ O.D. $\times 6.1 \mathrm{~m}$ long coiled metal sample tube that has an internal volume of $50 \mathrm{~cm}^{3}$.

The filter element utilizes the finest weave stainless steel mesh available and has a nominal filtering efficiency of about 1 micron. A more detailed description of the filter's construction is given by Barnes (1973).

The upper end of the sample tube is connected to an empty overflow cylinder that maintains a low internal pressure and collects excess filtered pore water. An adjustable spring-loaded check valve between the sample tube and overflow cylinder maintains the pore fluid sample at a positive pressure of up to 40 atm to prevent formation of gas bubbles in the fluid sample under all conditions except when the partial pressure of methane exceeds the set pressure.

When the sampler is prepared for use, the fluid inlet tubing and sample coil are filled with fresh water to eliminate air bubbles that could contaminate the collected pore-water sample. Sufficient pore fluid must be filtered to completely flush this fresh water from the sample tubing into the overflow cylinder.

The sampler takes the place of the lower half of a standard core-barrel assembly. The sampler core-barrel assembly is dropped down the drill pipe and latches into position above the drill bit with the filter probe extending through the drill bit for about 1 meter. The drill string is then lowered, pushing the filter probe into the bottom of the drill hole until 5000 to $15,000 \mathrm{lbs}$ of weight is resting on the bit. The sampler timer opens the sample control valve for a set time interval (5 to 10 minutes) and then closes it again. The drill string is raised off the bottom of the hole and the sampler corebarrel assembly is retrieved in the normal manner.

After successful recovery of a pore fluid sample, the metal sample tube is crimp-sealed at each end with refrigeration tubing clamps and removed from the sampler. The sample tube can be further divided into sub-samples for a variety of different analyses by crimpsealing segments of the 6.1-meter-long tube. 
Use of the in-situ sampler precludes recovery of a core during the round-trip of the inner core-barrel assembly described above. However, drilling is halted during this time so that little core would be lost between the preceding and succeeding standard core sections. Samples of core material from the bottom of the preceding core section or the top of the succeeding section should be squeezed for chemical comparison with the in-situ collected sample.

The use of the sampler is limited to sediments soft enough to be penetrated by the probe without fracture which would provide conduits for sea water contamination of the pore fluid sample.

\section{Physical Description of Sampler}

The working part of the sampler is illustrated in Figure 8 . The numbers in the text refer to the numbered components in the figure.

A stainless mesh filter element (1) is attached to the end of a filter probe that penetrates the sediment ahead of the drill bit. A motorized sampling control valve (8), when closed, prevents fluid flow into the sampler. When the control valve is open, hydrostatic pressure will force filtered pore fluid into the sampler.

A reversible DC motor (10) is connected to the control valve through a slip clutch (9) that prevents overtightening of the needle valve (8). The valve opens and closes in one turn. Travel is limited by a 3PDT switch (SW\#3) that is actuated by a lever attached to the torque handle. The switch limits rotation by shutting off the motor and reversing the polarity of the motor leads so that the motor reverses direction when it is re-energized by the timer.

A controller-timer (16) opens and closes the motorized valve (8) at appropriate times. A battery pack (14) supplies power to the motor and timer. A manual motor operation switch (SW\#2), mounted on the motor housing, permits one to open and close the control valve independently of the timer.

The pressure regulator (7) protects the sampler from excessive internal fluid pressure. The sample coil (11) collects the filtered pore fluid and is sealed and removed from the sampler after recovery. The check valve (12) maintains a positive pressure of several tens of atmospheres on the fluid in the sample coil to prevent gas bubble formation. The overflow cylinder (13) collects excess fluid and acts as a low pressure reservoir that maintains the pressure differential across the filter element. The pressure safety switch (SW\#1) consists of a spring-loaded hydraulic piston that closes a pushbutton DPDT switch when the pressure in the overflow cylinder reaches a preset amount. This switch then turns the motor on and closes the control valve independently of the timer.

An automotive shock absorber (5) protects the inner case assembly from excessive stress when the sampler impacts at the drill bit.

The sampler and its operation are discussed in more detail in the Operations Manual for the instrument that is available at DSDP headquarters in La Jolla, California, and on D/V Glomar Challenger.

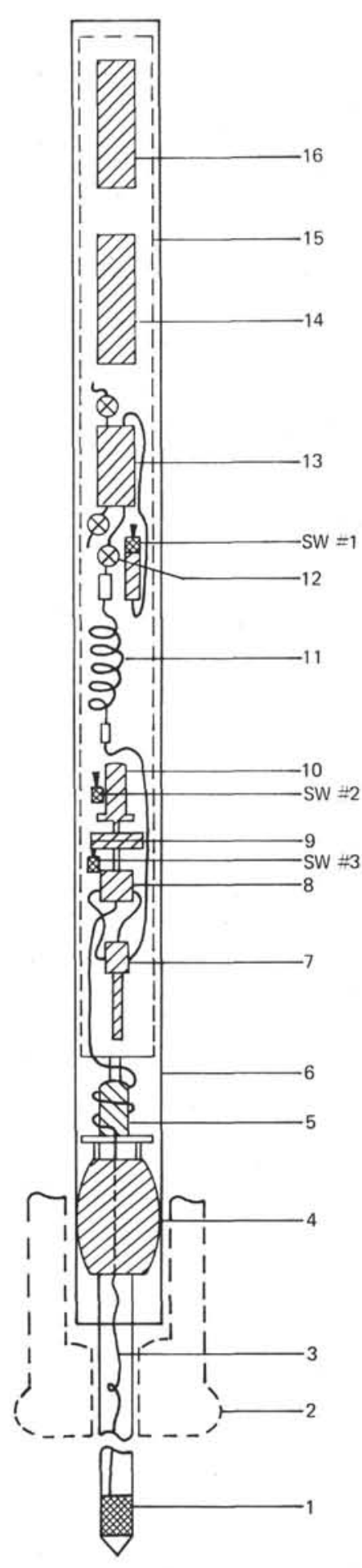

Figure 8. Schematic block diagram (not to scale) of the IPOD in-situ pore water sampler. (1) filter element, (2) drill bit, (3) 1/16 in. O. D. S. S. fluid inlet tubing, (4) lower sampler case bulkhead, (5) shock absorber, (6) pressure case, (7) pressure regulator, (8) sampling control valve, (9) torque handle, (10) D. C. gear motor, (11) sample coil, (12) high-pressure check valve, (13) overflow cylinder with drain valves on each end, (14) battery pack, (15) inner case assembly, (16) timercontroller. $S W \# 1$ = pressure safety switch, $S W \# 2$ $=$ manual motor switch, $S W \# 3=$ motor shut-off and reversing switch. 
The working part of the sampler above the lower bulkhead (4) is enclosed in a pressure case with double O-ring seals and bulkheads at each end. The filter probe attaches to the lower end of the lower bulkhead and the three standard lower sections of the inner core-barrel assembly screw over the probe and onto the lower bulkhead. The assembled tool is physically interchangeable with the lower section of the inner core-barrel assembly.

\section{Operational Tests}

The major goal of this initial cruise was to test the sampler operationally, determine needed modifications if necessary, and work out an operational procedure for the sampler's use.

The sampler was first lowered down the drill pipe on a wire cable (sand line) since we were reticent to free-fall a new untried instrument, although the sampler was constructed to hopefully withstand the rigors of freefalling.

The first downhole run at 110 meters sub-bottom depth in Hole 398 was successful. The sampler filtered a total of $84 \mathrm{~cm}^{3}$ of pore water in five minutes sampling time, of which $50 \mathrm{~cm}^{3}$ were collected in the metal sample tube.

The second downhole run at 232 meters sub-bottom depth in Hole 398B broke the sand line when retrieval was attempted. Fishing for the broken end of the cable was unsuccessful, and the drill string was raised almost to the surface before the sampler was retrieved. This was the second sand line to be broken, leaving both cables too short to reach anticipated basement for this site. The first sand line was broken in Hole 398 by the heat flow instrument during a downhole temperature measurement. Apparently, wire kinks caused by excess wire slack are a not-infrequent cause of cable breakage when downhole instruments are lowered on the sand line. Several wire breaks during attempted retrieval of the sampler unintentionally tested its resistance to freefall stresses. The sampler survived intact with no damage except that the pore fluid sample was diluted with sea water and lost because a small leak suddenly developed in the sample control valve (insufficient closing torque). This was a minor operational adjustment that was rectified.

With the major geological objectives of the leg jeopardized because of wire breaks, the in-situ sampler was put aside so that the major re-entry hole would not be subject to increased risk of failure.

The wire breaks during attempted retrieval demonstrated that the sampler can be dropped down the drill pipe and retrieved like a regular core barrel thus eliminating the extra risk of sand line breakage.

On subsequent legs, the sampler was lowered on the sand line using a different procedure than that used on Leg 47B; downhole water pumping during lowering of the sampler kept the sand line taut. No breaks occurred using this procedure, hence either free-fall or lowering on a line can be used to position the sampler at the drilling bit. The line is preferred because of greater control on speed of descent and less impact shock to the instrument.
To further test the sampler's ability to operate in a free-fall mode and to check the operation of the safety systems that prevent flooding when the sampler opens in sea water with no hydraulic filtering resistance, a third downhole run was made after Hole 398D was terminated and plugged, and the drill string was pulled above the ocean floor. There was no probe attached to the sampler; water could enter through the open tubing connection on the lower bulkhead. The sampler was allowed to free-fall down the drill pipe. To save time, it was not recovered with the sand line, but came up as the drill string was raised to the ship. All parts of the sampler, including the safety systems, functioned as intended, with no damage. It returned full of sea water.

\section{Geochemical Tests}

Barnes et al. (this volume) compare the chemical analyses obtained on the in-situ pore-water sample with the analytical data for the water samples squeezed from core sections.

All of the sampler plumbing in contact with the collected sample is stainless steel (primarily type 316) except for the sample coil itself which was constructed of copper refrigeration tubing. This tubing is inexpensive; it can be crimp-sealed and reopened by removing the crimping device and is not subject to diffusive gas loss through the tubing walls during storage. The latter two factors are important for shore-based gas concentration studies.

Copper reacts readily with sea water so that samples stored in this tubing would be unsuitable for some chemical analysis. Leg 47B was primarily an operational trail for the in-situ sampler. There was insufficient precruise time to test the copper coil for all possible chemical effects.

During and subsequent to Leg 47B, we investigated the effects of the copper coils on some of the shipboard analytical procedures. The copper tubing as received is cleaned and sealed for refrigeration service. Analysis of sea water stored in this tubing showed apparent increases in alkalinity, calcium, and magnesium. When the tubing was cleaned with a detergent and flushed with distilled water, the tubing effect on the calcium and magnesium concentrations was essentially eliminated, but alkalinity continued to show an approximate 6 per cent increase.

To eliminate these undesirable chemical effects of the copper tubing, we are now using a double sample coil. The lower $10 \mathrm{~cm}^{3}$ is constructed of teflon-coated stainless steel and is used for chemical analysis. The $50-\mathrm{cm}^{3}$ copper coil is attached to the upper end of the stainless tube and is crimped off for shore-based gas studies.

\section{Summary}

We successfully tested a new in-situ pore-water sampler that should provide valuable new geochemical information on subsequent legs of the IPOD program. The sampler is operational as used on Leg 47B, but several modifications will be made for increased mechanical reliability and ease of use. Modifications to the sample collection coil will continue to be made to pro- 
vide more reliable chemical data and to provide for additional analytical programs.

\section{ACKNOWLEDGMENTS}

This work was supported by NSF Grants OCE76-20151 to University of California, San Diego and NSF Grant DES7519383 to Walla Walla College. I would like to thank Joris M. Gieskes for his assistance in initiating this project. The successful use of the sampler was in large measure the product of the cooperation and assistance of the DSDP staff during instrument design and initial testing on Leg 47B.

\section{REFERENCES}

Bader, R. G. et al., 1970. Initial Reports of the Deep Sea Drilling Project, v. 4, Washington (U.S. Government Printing Office), p. 745-753.

Barnes, R. O., 1973. An in situ interstitial water sampler for use in unconsolidated sediments, Deep-Sea Res., v. 20, p. $1125-1128$.

Barnes, R. O. and Bieri, R. H., 1976. Helium flux through marine sediments of the northeast Pacific Ocean, Earth Planet. Sci. Lett., v. 28, p. 331-336.

Bennett, R. H. and Keller, G. H., 1973. Physical properties evaluation. In van Andel, T. H., Heath, G. R., et al., Initial Reports of the Deep Sea Drilling Project, v. 16: Washington (U.S. Government Printing Office), p. 513-519.

Boyce, R. E., 1972. Grain size analyses, Leg 9. In Hays, J. D. et al., Initial Reports of the Deep Sea Drilling Project, v. 9: Washington (U.S. Government Printing Office), p. 779798.

1973. Physical properties-methods. In Edgar, N. T., Saunders, J. B., et al., Initial Reports of the Deep Sea Drilling Project, v. 15: Washington (U.S. Government Printing Office), p. 1115-1127.

Boyce, R. E. and Bode, G. W., 1972. Carbon and carbonate analyses, Leg 9, Deep Sea Drilling Project. In Hays, J. D., et al., Initial Reports of the Deep Sea Drilling Project, v. 9: Washington (U. S. Government Printing Office), p. $797-$ 816.

Goddard, E. N., et al., 1963. Rock color chart: New York (Geol. Soc. Am.).

Hedgepeth, J. W., 1957. Classification of marine environments, Geol. Soc. Am. Mem. 67, v. 1, p. 17.

Jones, J. B. and Segnit, E. R., 1971. The nature of opal, in Nomenclature and constituent phases, J. Geol. Soc., Australia, v. 18, p. 57-68.

Kullenberg, B., 1952. On the salinity of the water contained in marine sediments, Medd. Oceanografiska Inst. Goteborg, v. 21.

Matthews, D. J., 1939. Tables of the velocity of sound in pure water and in seawater: Admiralty, London (Hydrographic Department).

Mazor, E., 1972. Paleotemperatures and other hydrological parameters deduced from noble gases dissolved in groundwaters; Jordan Rift Valley, Israel, Geochim. Cosmochim. Acta, v. 36 , p. $1321-1336$.

Müller, G. and Gastner, M., 1971. The "karbonate bombe"; a simple device for the determination of the carbonate content in sediments, soils and other materials, $N$. Jb. Miner. Mh., v. 10, p. 466-469.

Waterman, L. S., 1970. Interstitial water program, Shipboard Manual, Deep Sea Drilling Project Manuscript Rep., May 1970: Scripps Institution of Oceanography, p. 141.

Wentworth, C. K., 1922. A scale of grade and class terms of clastic sediments, J. Geol., v. 30, p. 377.

Wentworth, C. K. and Williams, H., 1932. The classification and terminology of the pyroclastic rocks, Rept. Comm. Sed. Nat. Research Council, Bull. 89, p. 19-53.

Whitmarsh, R. B., Weser, O. E., and Ross, D. A., 1974. Explanatory notes. In Whitmarsh, R. B., Weser, O. E., Ross, D. A., et al., Initial Reports of the Deep Sea Drilling Project, v. 23: Washington (U. S. Government Printing Office), p. 20-29. 